„Kwartalnik Filmowy” nr 112 (2020)

ISSN: 0452-9502 (Print) ISSN: 2719-2725 (Online)

https://doi.org/10.36744/kf.496

(c) Creative Commons BY-NC-ND 4.0

Jacek Szymala

Uniwersytet Wrockawski

https://orcid.org/0000-0002-8714-7114

Andrei Rogatchevski

Uniwersytet w Tromsø

https://orcid.org/0000-0003-3326-8719

\title{
Svalbard w filmach polskich z lat 30. XX wieku
}

\author{
Słowa kluczowe: \\ Svalbard; \\ Arktyka; \\ historia wizualna
}

\begin{abstract}
Abstrakt
W 2020 r. minęła 100. rocznica zawarcia traktatu svalbardzkiego, na mocy którego archipelag ten przyznano Norwegii. Polska podpisała go w $1931 \mathrm{r}$. W roku następnym rozpoczęły się polskie wyprawy polarne. Ekspedycje te były związane z badaniami prowadzonymi z punktu widzenia nauk przyrodniczych, a ekipom towarzyszyli także fotografowie i/lub filmowcy. Celem artykułu jest przedstawienie, analiza i interpretacja materiału wizualnego, jaki pozostał po tych wyprawach, głównie filmowego. W tekście zostały omówione trzy produkcje z lat 30. (Wyspa mgiet i wichrów, Wśród mórz Arktyki oraz Do Ziemi Torella) stanowiące źródła z obszaru historii wizualnej. Filmy te mogą pomóc w studiowaniu historii nauki, zmian krajobrazu, historii cywilizacji oraz w analizowaniu badań polarnych itd.; są także ciekawym głosem na temat polskiej historiografii dotyczącej Arktyki. Autorzy tekstu poświęcają szczególną uwagę odnalezionemu w 2019 r. reportażowi Do Ziemi Torella (reż. Witold Biernawski). Istotną część opracowania stanowi zamieszczona na końcu tabela, w której znajdują się informacje o 40 polskich filmach na temat Svalbardu.
\end{abstract}




\section{Svalbard i traktat svalbardzki}

Svalbard to arktyczny archipelag składający się z następujących wysp: Spitsbergen Zachodni (37 673 km²), Ziemia Północno-Wschodnia (Nordaustlandet, 14443 km²), Wyspa Edge'a (Edgeøya, 5074 km²), Wyspa Barentsa (Barentsøya, 1250 km²), Wyspa Biała (Kvitøya, 682 km²), Ziemia Księcia Karola (Prins Karl Forland, 615 km²), Wyspa Królewska (Kongsøya, 191 km²), Wyspa Niedźwiedzia (Bjørnøya, 178 km²), Wyspa Szwedzka (Svenskøya, 137 km²), Wyspa Wilhelma (Wilhelmøya, 120 km²), Wyspa Nadziei (Hopen), Wyspa Niska (Lågøya), Wyspa Wielka (Storøya), Abeløya i kilkuset mniejszych ${ }^{1}$. Często mianem Spitsbergenu (dawniej także Spitzbergenu) nieprecyzyjnie określano cały archipelag, a nie tylko największą z wysp.

Kwestie prawne związane $\mathrm{z}$ władzą i zagospodarowaniem tych wysp uregulowano po I wojnie światowej. Precyzuje je traktat svalbardzki (spitsbergeński) zawarty 9 lutego 1920 r. w Sèvres pod Paryżem, określający warunki komercyjnego i naukowego eksplorowania tego obszaru przez sygnatariuszy ${ }^{2}$. Badania naukowe tego regionu rozpoczęły się w XIX w., natomiast duże znaczenie dla podpisania traktatu miała intensyfikacja ekspedycji norweskich, których od 1906 r. odbyło się kilkanaście (21 w latach 1906-1926) 3 . Na mocy traktatu Svalbard należy do Norwegii. Zarządza nim gubernator. Norwegowie oficjalnie rozpoczęli administrowanie archipelagiem po wejściu traktatu w życie, 14 sierpnia 1925 r. ${ }^{4} 2$ września 1931 r. sygnatariuszem traktatu stała się II Rzeczpospolita Polska. Już w następnym roku zorganizowano pierwszą polską wyprawę polarna, której celem była Wyspa Niedźwiedzia ${ }^{5}$. Do wybuchu wojny przeprowadzono jeszcze kilka polskich ekspedycji polarnych (trzy wyprawy na Spitsbergen: w 1934, 1936 i 1938 r. oraz wyprawę na Grenlandię w 1937 r.).

Badania naukowe Svalbardu od początku prowadzono głównie z perspektywy nauk przyrodniczych, głównie nauk o Ziemi, w tym geografii, geologii i innych. Rzadziej były to ustalenia przygotowywane według metodologii nauk politycznych lub społecznych, na przykład w związku z eksploatacją złóż, głównie węgla. Przy okazji rocznic podejmowano studia z historii nauki (przede wszystkim geografii, geologii itd.), opracowywane zresztą przez samych przyrodników, a nie historyków ${ }^{6}$. Natomiast poszczególnym wyprawom towarzyszyły przeważnie ekipy filmowe i/lub fotograficzne, pozostawiając materiał wizualny. Dotychczas materiał ten pełnił funkcję służebna, przedmiotowa, jako oprawa dokumentująca istotne wydarzenia (polityczne, naukowe lub gospodarcze). Zdjęcia i filmy nie były analizowane jako przedmiot badań.

Obchodzone w 2020 r. stulecie zawarcia traktatu svalbardzkiego daje okazję do podjęcia głębszych (i pionierskich) studiów nad tym materiałem, zwłaszcza ze względu na odnalezienie przez Jacka Szymalę reportażu filmowego z pierwszej polskiej ekspedycji na Spitsbergen, czyli filmu Do Ziemi Torella w reżyserii Witolda Biernawskiego ${ }^{7}$. Proponujemy wobec tego szerokie badania z wykorzystaniem aparatu metodologicznego nauk humanistycznych, głównie historii wizualnej i filmoznawstwa. Konieczne będą także wyjaśnienia i komentarze wykorzystujące ustalenia nauk przyrodniczych, bowiem wiele filmów stanowiło dokumentację badań w zakresie nauk ścisłych. W niniejszym opracowaniu, będącym pierwszą częścią większej całości, przyjrzymy się obrazowi Svalbardu w pierwszych polskich 
filmach na ten temat. W pewnej mierze będzie to komparatystyka - spróbujemy porównać, jak portretowano lub obrazowano sylwetki naukowców pracujących „w terenie”. Istotne jest dla nas także, jak przedstawiano sam krajobraz (czy Svalbard jawi się jako groźne, niegościnne pustkowie, czy - jak będzie to w późniejszych filmach Włodzimierza Puchalskiego - ze względu na bujną w lecie florę i faunę, wręcz zachęca do odwiedzin) ${ }^{8}$. Na końcu opracowania zamieściliśmy filmografię wykraczającą chronologicznie poza dekadę lat 30. Zamierzeniem tego zestawienia jest zwrócenie uwagi na poważne rozmiary korpusu źródłowego. Skatalogowaliśmy ponad 30 polskich filmów na temat Svalbardu, które w przeważającej mierze nie mają literatury przedmiotu lub były zaledwie wzmiankowane w fachowej prasie jako plon dokumentacji poszczególnych wypraw.

\section{Wyspa Niedźwiedzia - ekspedycja i filmy}

Polska ekspedycja na Wyspę Niedźwiedzią wiązała się z zaplanowanym na przełom 1932 i 1933 r. II Międzynarodowym Rokiem Polarnym (International Polar Year) ${ }^{9}$. I Międzynarodowy Rok Polarny ustanowiono pięćdziesiąt lat wcześniej (1882-1883 r.), kolejny ogłoszono zaś na rok 1957. Była to pierwsza polska wyprawa na wyspę, a szesnasta w ogóle. Wyprawą kierował dyrektor Państwowego Instytutu Meteorologicznego dr inż. Jean Lugeon (1898-1976) ${ }^{10}$. Wzięły w niej udział trzy osoby: Czesław Centkiewicz (1904-1996), Władysław Łysakowski (1905-194011) i Stanisław Siedlecki (1912-2002) ${ }^{12}$. Doświadczenia z pobytu na wyspie zainspirowały Centkiewicza do napisania książki Wyspa mgieł i wichrów. Pierwsza polska ekspedycja narodowa roku polarnego 1932/33, wydanej po raz pierwszy w 1934 r. Książka była wielce popularna, o czym świadczą kolejne edycje (6 wydań do 1957 r.) i wznowienia (ostatnie w 2012 r.). Zarówno sama wyprawa, jak i dorobek literacki Centkiewicza były już przedmiotem rozważań naukowych.

Nie był natomiast dotąd przedmiotem analiz film o tym samym tytule, czyli zrealizowany przez operatora (operatorów) Polskiej Agencji Telegraficznej materiał o długości jednej minuty i jedenastu sekund zamieszczony i udostępniony na stronie internetowej Repozytorium Filmoteki Narodowej ${ }^{13}$. Film opisano jako wykonany w 1937 r. Zrealizował go zapewne Czesław Centkiewicz podczas pobytu na wyspie w 1936 r. ${ }^{14}$ Film można potraktować jako adaptację książki Centkiewicza Znowu na pótnocy (pośrednio również jako adaptację Wyspy mgiet i wichrów, zwłaszcza ze względu na tytuł), a także jako echo mikrohistorii wizualnej zimowania trzech polskich przyrodników na Wyspie Niedźwiedziej (1932-1933). Plansza tytułowa zapowiada: Wyspa mgiet i wichrów. Polacy za kręgiem polarnym. Wspomnienia zimy polarnej, spędzonej na Wyspie Niedźwiedziej przez polska ekspedycję naukowa w ramach Międzynarodowego Roku Polarnego ${ }^{15}$. Od ósmej sekundy, w dwóch krótkich ujęciach (łącznie trwających 8 sek.), widzimy budynek polskiej ekspedycji polarnej (w pierwszym wydaniu książki Centkiewicza fotografia przedstawiająca tę budowlę jest infantylnie podpisana jako domek Polskiej Ekspedycji Polarnej, a w opracowaniu Piotra Köhlera to stała baza Polskiej Wyprawy na Wyspę Niedźwiedziq"). Dwukondygnacyjny budynek, oddalony około $200 \mathrm{~m}$ od stacji norweskiej, został wyremontowany przez rząd Norwegii i udostępniony Polakom. Köhler uściślił: Na parterze, w dwóch wielkich pokojach urządzono pracownie. Na tej kondygnacji mieściła się też kuchenka, mała spiżarnia oraz malutkie pomieszczenie na akumulatory. 
W pomieszczeniach na piętrze umieszczono warsztat mechaniczny i magazyn żywności. $W$ dwóch pokojach przygotowano sypialnie ${ }^{16}$. Głos spoza kadru informuje, że [dom, w którym?] przebyli długa zimę polarna stoi tu jeszcze w otoczeniu stojaków, na których ustawione były instrumenty meteorologiczne. Po tym fragmencie następują ujęcia krajobrazu przedstawiające wybrzeże wyspy. Po kilku sekundach narrator kontynuuje: na zboczach [?] gnieżḋ̇a się niezliczone stada polarnego ptactwa, wijąc gniazda wśród niedostępnych skalistych bastionów. Obfitość ptactwa zapewnia [na?] długie lata pokarm dla jedynego mieszkajacego tu czworonoga, klaczy pociagowej, która wbrew zwyczajom swej rasy żywi się surowym mięsem pierzastych lokatorów tej skalistej wyspy. Słowom tym towarzyszy groźna muzyka, ujęcia ulegają skróceniu, widz może odczuć grozę miejsca. W filmie pokazano znaną z książki Centkiewicza klacz Blakkę. Centkiewicz wymienił jeszcze psa Bramse. W lecie 1994 r. Adam Krawczyk z Uniwersytetu Jagiellońskiego postanowił odszukać na Wyspie Niedźwiedziej ślady polskiej przedwojennej wyprawy. Stwierdził: na Wyspie Niedźwiedziej nie ma praktycznie żadnego śladu, że działała tutaj polska wyprawa ${ }^{17}$. Do śladów znajdujących się poza wyspą zaliczył opublikowane wyniki badań polarników, w tym wspomnianą książkę Centkiewicza składającą się z 360 listów adresowanych do ówczesnej narzeczonej Aliny. Krawczyk ocenił wręcz, że ksiażka pozostaje najtrwalszym i powszechnie znanym śladem pierwszej polskiej wyprawy polarnej ${ }^{18}$. Ponadto wymienił krótką relację Stanisława Siedleckiego W górach Wyspy Niedźwiedziej i rozdział z jego książki Wśród polarnych pustyń Svalbardu. Można dodać, że śladem czy echem tej wyprawy jest też opisany wyżej film, niewymieniany przez autorów zajmujących się „narracjami polarnymi”.

Również w 1937 r. został zmontowany drugi krótki materiał (temat) filmowy, zrealizowany przez Polską Agencję Telegraficzną pod tytułem Wśród mórz Arktyki $i^{19}$. Oba filmy, oprócz instytucji, która je wykonała ${ }^{20}$, łączy osoba Centkiewicza. Wśród mórz Arktyki rozpoczyna się słowami: Znany uczestnik polskiej wyprawy polarnej na Wyspę Niedźwiedzia, inżynier Stanisław Centkiewicz [błędnie podano imię ojca, zamiast syna], nadsyła nam serię zdjęć filmowych ze swej ostatniej podróży na pokładzie statku wielorybniczego wśród mórz Arktydy ${ }^{21}$. Dalsze słowa komentarza są następujące: Flotylla tych statków wyrusza na łowy w okresie tak zwanego lata polarnego, mało różniącego się zreszta w tych stronach od naszej zwykłej zimy. Oprócz wielorybów statki te poluja również na foki i morsy, których stada używaja wywczasów letnich na krach lodowych. Skóry upolowanych zwierząt stanowia cenny tup statków myśliwskich, pokrywając ryzyko wyprawy, połaczonej z ciagła walka z fala arktyczna $i$ niebezpieczeństwem zamknięcia przez lody22. W kadrach widzimy realia pracy wielorybników: płynące statki, morsa na krze lodowej, polowanie, upolowanego morsa, rybaków sprawiających skórę foki i jednego z pracowników pokazującego fokę.

\section{Do Ziemi Torella - wyprawa i film}

Choć oba filmy powstały w 1936 r., a były wyświetlane w roku kolejnym, dotyczyły pośrednio wyprawy na Wyspę Niedźwiedzią w latach 1932-1933. W 1934 r. odbyła się pierwsza polska ekspedycja na Spitsbergen. Podobnie jak wcześniejsza, jest dobrze opracowana ${ }^{23}$ i niżej zostanie jedynie krótko przedstawiona. Bardziej skupimy się na odnalezionym w 2019 r. reportażu Do Ziemi Torella. 
Od razu po zakończeniu ekspedycji na Wyspę Niedźwiedzią rozpoczęły się przygotowania do kolejnej wyprawy, której celem miał być Spitsbergen. W lutym 1934 r. zawiązano Komitet Organizacyjny Polskiej Wyprawy Polarnej na Spitsbergen. Na jego czele stanął profesor Antoni B. Dobrowolski, a zastępcą został kierownik wspomnianej wyprawy z 1932 r. inż. Jean (Jan) Lugeon. Podobnie jak poprzednio, istotne były doświadczenia wysokogórskie. Wyprawę zainicjowało Koło Wysokogórskie przy Oddziale Warszawskim Polskiego Towarzystwa Tatrzańskiego, współorganizatorem był Zakład Geologii i Paleontologii Uniwersytetu Warszawskiego i Wojskowy Instytut Geograficzny. Planowano zbadać Ziemię Torella, a więc południową część wyspy Spitsbergen pomiędzy fiordami Van Keulen na północy i Hornsund na południu. Była to jedna z najmniej znanych pod względem naukowym części wyspy (wcześniejsze badania koncentrowały się głównie na wybrzeżu, a głębi Ziemi Torella nie penetrowano). Nazwa miejsca oraz tytuł filmu pochodzą od nazwiska szwedzkiego geologa i zoologa Otto Martina Torella (1828-1900), który m.in. dowiódł, że nie tylko Skandynawia, ale także Europa Środkowa była niegdyś pokryta lodowcami.

Podczas trwania wyprawy powstały dwa filmy ${ }^{24}$ : Do Ziemi Torella oraz Ku wiecznym lodom Spitsbergenu. Materiał filmowy zrealizował i zmontował jeden z uczestników, Witold Biernawski, ponad to Henryk Mogilnicki wykonał przeszło 200 fotografii. Wiadomo, że film Do Ziemi Torella nie był poddany cenzurze w Norwegii, a pokaz odbył się 17 września 1936 r. w Oslo (dawniej: Christianii), w kinie Victoria przy Karl Johans gate $35^{25}$. Ta główna ulica miasta, na której wiele się dzieje, jest szczególnie istotna na mapie miejsc znaczących dla polsko-norweskiej historii wizualnej, zwłaszcza że przy Karl Johans gate 4 powstaniec styczniowy Ludwik Szaciński (1844-1894) otworzył w 1888 r. studio fotograficzne ${ }^{26}$.

\section{Premiera i recepcja Do Ziemi Torella}

Jesteśmy w stanie wymienić widzów obecnych na premierze Do Ziemi Torella w 1936 r. Zaproszono szereg członków korpusu dyplomatycznego, wybitnych norweskich pilotów i badaczy polarnych, kilku członków polskich ekspedycji i szereg innych zainteresowanych" 27 , w tym dziennikarzy. Według niepodpisanego sprawozdania pod tytułem Interessant polsk Svalbard-film, opublikowanego w gazecie „Morgenbladet" 18 września 1936 r., obecny był polski ambasador w Oslo w latach 1931-1940 Władysław Neuman (1893-1945), norweski ambasador w Warszawie w latach 1919-1923 Sam Eyde (1866-1940), gubernator Svalbardu w latach 1932-1933 oraz 1935-1942 Wolmer Tycho Marlow (1881-1963). Obecny był również Aksel Kristofer Abrahamsen Hillestad (1871-1946), Dyrektor Generalny przy norweskim Ministerstwie Handlu, Hans Theodor Hesselberg (1885-1966) - dyrektor Norweskiego Instytutu Meteorologicznego w latach 1915-1955, Hjalmar Ruud Batt (1873-1946) - członek załogi (w latach 1929-1941) Store Norske Spitsbergen Kullkompani (główna norweska spółka górnicza na Svalbardzie), Carl Bugge (1881-1968) - prezes norweskiej Służby geologicznej w latach 1921-1951 oraz wielu emerytowanych norweskich kartografów związanych z Norges geografiske oppmåling.

W wydawanym w Oslo czasopiśmie „Tidens Tegn”, w numerze z 18 września 1936 r., w anonimowym artykule Polsk Svalbard-film på Victoria informowano czytelników, że Neuman był współorganizatorem pokazu wraz z instytucją Nor- 
ske Svalbard- og ishavsundersøkelser (poprzednik Norwegian Polar Institute). Twórca i dyrektor tego instytutu, Adolf Hoel (1879-1964), w prelekcji wprowadzającej pochwalił polskie ekspedycje z lat 1932-1936 nagłówkiem w „Tidens Tegn” jako uzyskujace świetne rezultaty.

Autor anonimowej recenzji w „Morgenposten” (Oslo) w numerze z 18 września 1936 r., w artykule En polsk film om Svalbard relacjonował, że członkowie polskiej ekspedycji prowadzili badania meteorologiczne, geologiczne i botaniczne, a także miernicze. Wykonano również mapy nieznanych wcześniej terenów. Z kolei według słów opublikowanych w "Norsk Tidend” (zob. Polakkar krossar Svalbard på langs, tekst sygnowany akronimem „, $\left.\mathrm{V}^{\prime \prime}\right)$, w numerze z 18 września 1936 r., nazwy takie jak Pitsudskifjellet, Kopernikusfjellet i Polakkbreen potwierdzaja teraz, dokad dotarli synowie Polski. Na pokazie było dwóch członków ekspedycji: Stanisław Siedlecki oraz Konstanty Narkiewicz-Jodko (1901-1963).

Pokaz był zamknięty ${ }^{28}$, ale kino, według doniesień prasowych, było pełne. Na podstawie wymienionych notek prasowych można mówić o recepcji Do Ziemi Torella w prasie norweskiej i stwierdzić, że film się podobał ${ }^{29}$. Profesor Stefan Alexandrowicz (ur. 1930 r.) w rozmowie-wspomnieniu o Witoldzie Biernawskim zasugerował nawet, że ze względu na to, iż film podobał się Norwegom, dla upamiętnienia reżysera jego nazwiskiem nazwano jeden $\mathrm{z}$ lodowców ${ }^{30}$. W artykule opublikowanym w „Morgenposten” Do Ziemi Torella sklasyfikowano jako „Kulturfilm" (gatunek związany z kinem niemieckim lat 20.) i stwierdzono, że wyznacza on drogę norweskim filmowcom i badaczom ${ }^{31}$.

Do Ziemi Torella został oceniony także w prasie polskiej. W recenzji opublikowanej w czasopiśmie „Kurjer Warszawski” w 1935 r. anonimowy autor porównał film do Wyprawy admirała Byrda do Bieguna Południowego ${ }^{32}$, zwłaszcza $\mathrm{w}$ aspekcie wspaniatych zdjęć, stojących na wyżynie najlepszych filmów tego rodzaju . $^{33}$. Podobne porównanie pojawiło się w „Wiadomościach Filmowych” z 1935 r. Dzięki tym dwóm publikacjom wiadomo także, że w tym samym czasie powstał drugi film, Ku wiecznym lodom Spitzbergenu. Na temat obu dzieł Biernawskiego w „Kurjerze Warszawskim" napisano: Wyprawa nie tylko dokonała niezwykle cennych odkryć topograficznych i geologicznych, ale przywiozła ze soba także kilka tysięcy metrów taśmy filmowej. Z tysięcy metrów taśmy filmowej wybrano najciekawsze momenty, z których stworzono dwa niezwykle ciekawe filmy (...). Zdjęcia tych filmów maja podwójna wartość: jako dokument i jako niezwykle interesujacy film. Wybitnie ciekawa akcja odkrywcza, praca petna niebezpieczeństw, wśród groźnych szczytów i lodowców gór polarnych, życie obozowe podczas nocy polarnych, petne swoistego humoru, wspaniate zdjęcia ${ }^{34}$.

\section{Ponowne odkrycie Do Ziemi Torella. Klasyfikacja i treść filmu}

Do Ziemi Torella udało się odnaleźć "ponownie” (film znała i cytowała jego fragmenty Wanda Rollny w dokumencie Stanisław Siedlecki z 1988 r.) w połowie 2019 r. podczas kwerendy związanej z poszukiwaniem innych polskich materiałów wizualnych dotyczących Svalbardu, a znajdujących się w archiwum Wytwórni Filmów Oświatowych w Łodzi. Ukonstytuował się wówczas międzynarodowy polsko-norweski projekt badawczy, którym kierujemy. Pośrednio inspiracją było wydanie w 2017 r. pięciu „,arktycznych” filmów Włodzimierza Puchalskiego w for- 

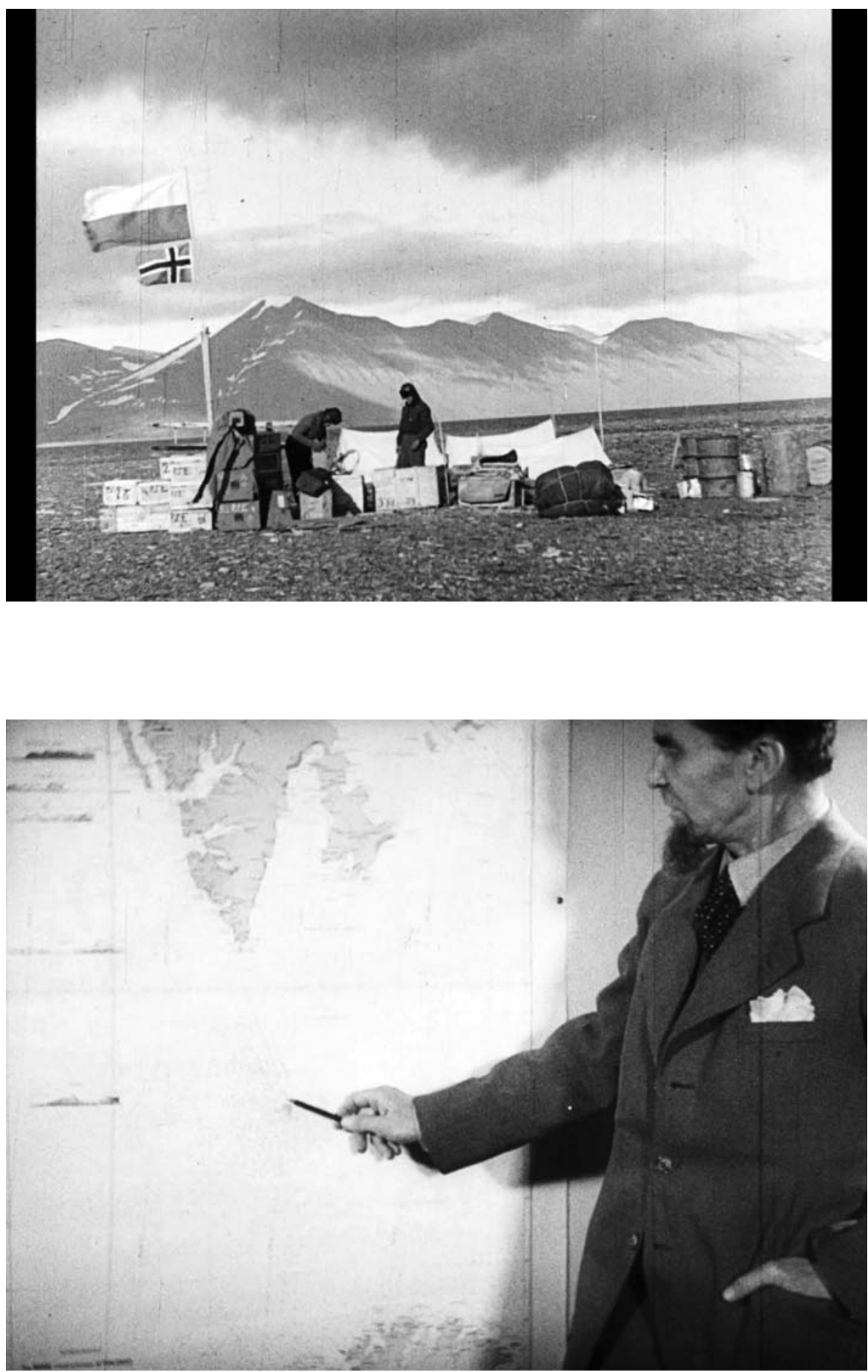
macie DVD z dołączoną broszurą autorstwa Jana Walencika. We współpracy z archiwistami z Wytwórni Filmów Oświatowych w Łodzi (Jakub Krakowiak, Marek Pelski) Do Ziemi Torella został zdigitalizowany ${ }^{35}$ wraz z filmem Włodzimierza Puchalskiego Wśród gór i dolin Arktyki oraz Szpicbergi (reż. Jarosław Brzozowski). Oprócz tego dodano napisy w języku angielskim, aby materiał przygotować do międzynarodowego obiegu naukowego.

Odnaleziony materiał został skopiowany na taśmy trudnopalne $35 \mathrm{~mm}$ (w postaci duplikatu negatywu obrazu i tonu oraz kopii wzorcowej). Oryginalne materiały się nie zachowały. Reportaż urywa się w dziewiątej minucie i dwudziestej drugiej sekundzie (być może uda się jeszcze odnaleźć dalszą część). Zachowana część pierwsza sugeruje, że był to film przynajmniej średniometrażowy. Nie można go uznać jedynie za „suchą” dokumentację wyprawy, gdyż jego „bohaterowie" - są nimi autentyczni uczestnicy prawdziwych wydarzeń - zostali zaprezentowani niczym w filmie przygodowym lub wojennym (przychodzi na myśl adaptacja Na Zachodzie bez zmian, zarówno wersja z 1930 r. w reżyserii Lewisa Milestone'a, jak i późniejsza z 1979 r. w reżyserii Delberta Manna ${ }^{36}$ ). Również uznanie go za film dokumentalny nie jest precyzyjne ze względu na fabułę rozpoczynająca się w ostatnich minutach zachowanego fragmentu. Zresztą z punktu widzenia historii wizualnej podział na dokument i fabułę jest jedynie wyznacznikiem formalnym i nie ma znaczenia ze względu na wartość źródłową ${ }^{37}$. Granica między filmem dokumentalnym a fabularnym jest często płynna.

Argumentem za uznaniem filmu za średnio- lub długometrażowy oraz podstawą ostrożności w jego klasyfikacji gatunkowej i formalnej jest także proporcja: wyświetlanie plansz z napisami trwa ponad minutę.

Napisy każdej z plansz są wkomponowane w awangardowe przedstawienia krajobrazów lub motywów podróży. Na pierwszej jest napis: PANTA-FILM ma zaszczyt przedstawić. Następnie, z użyciem tzw. roletki montażowej, jest pokazana druga plansza: Dzieje polskiej wyprawy polarnej na Spitsbergen w filmie pt. (treść tego zdania to interesujące określenie historii wizualnej). Dalej, na tle płatków śniegu i umownej sylwetki dwumasztowego statku, pojawia się napis: Do Ziemi Torella, a na następnej planszy, przedstawiającej pochylonego mężczyznę (zapewne alpinistę), który ciągnie linę, i wbity w śnieg czekan, tekst informuje o autorze: Zdjęcia i opracowanie filmu: inż. Witold Biernawski. Już na tym etapie można zauważyć ścisły związek obrazu i tekstu - ilustracje te mogą być postrzegane jako swoiste wizytówki opisywanych miejsc lub postaci, jak w przypadku reżysera - taternika, który rok wcześniej uratował w górach rodzinę przyszłego profesora geologii, Stefana Alexandrowicza. Napis na piątej planszy informuje: Kierownictwo artystyczne: Ferdynand Goetel.

Zatrzymajmy się przy wspomnieniu tej postaci. Goetel (1890-1960) jeszcze przed I wojną światową był taternikiem. W okresie międzywojennym zasłynął jako pisarz awangardowy. Po wojnie przebywał na emigracji. Władze PRL cenzurowały jego twórczość pod zarzutem współpracy z Niemcami (w 1943 r. z ramienia Czerwonego Krzyża badał zbrodnię katyńską). W okresie powstania filmu był prezesem Związku Literatów Polskich.

Z szóstej planszy, którą ze względu na warstwę wizualną można nazwać „narciarską", dowiadujemy się o kolejnych twórcach: Tekst muzyczny: Roman Palester, Marian Neuteich, a z siódmej - o produkcji: Atelier i laboratorium: Falanga. Ton: 
Tobis-Klagenfilm. Wymienione plansze filmowane są przez 38 sekund. Ze względu na ich formę film można określić jako awangardowy.

W filmie widzimy obracający się model kuli ziemskiej. Gdy pojawia się zarys Europy, następuje zbliżenie na jej część skandynawska, po czym w następnym ujęciu mamy fragment mapy plastycznej archipelagu Svalbard ze zbliżeniem na południową część wyspy Spitsbergen. Widzimy dłoń wbijającą pinezkę w środek Ziemi Torella. Podobną formę zaznaczenia tego miejsca na mapie zastosowano w 13. numerze pisma „Wierchy” z 1935 r. - Ziemię Torella wskazuje tam gigantyczna strzała, mająca w lotce dwukolorową flagę i datę „1934”. Podobieństwo nie jest przypadkowe, zważywszy na fakt, że redaktorem czasopisma był wówczas Walery Goetel (1899-1972), o rok starszy brat Ferdynanda, kierownika artystycznego filmus ${ }^{38}$.

Pierwsza, obszerna, nieanimowana sekwencja wprowadza poważny, naukowy ton. Sfilmowano bowiem krótki (ale na jednym, długim ujęciu) wykład profesora Dobrowolskiego - klasyczną „lekcję” geografii, w której omówił i pokazał na mapie miejsca związane z wyprawą (kontynentalna Norwegia, Wyspa Niedźwiedzia, Spitsbergen, Ziemia Torella „i jej nieznane wnętrze”). Widzimy, jak nestor polskich badań polarnych gestami usiłuje tuszować stres. Te migawki pokazują spotkanie dwóch światów - XIX-wiecznej belle epoque, tradycyjnych badań przyrodniczych reprezentowanych przez „starą szkołę” Dobrowolskiego, w zderzeniu z „nowinkami” medialnymi w rodzaju filmu dźwiękowego. Jakub Romaniak zauważył, że ta „wstawka”, mająca na celu uwiarygodnienie dalszej narracji, przypomina początek duńsko-szwedzkiego filmu Benjamina Christensena Czarownica (1922), gdzie również jest takie wprowadzenie. Natomiast Agata Lubowicka zauważyła, że ukazana na pierwszej planszy zapowiadającej wykład śnieżynka pochodzi z książki Dobrowolskiego z lat 20. - pierwszej polskiej monografii lodu ${ }^{39}$. Można ją zatem zinterpretować jako „wizytówkę” lub rys portretu naukowego, analogiczny do wcześniejszego przedstawienia Biernawskiego. Warto wspomnieć, że Dobrowolski kierował tzw. Kołem Polarnym założonym przy Towarzystwie Geofizyków w Warszawie przez uczestników wyprawy na Wyspę Niedźwiedzią w latach 1932-1933 r., a wcześniej, jeszcze w XIX w. (1897-1899), wziął udział w słynnej wyprawie antarktycznej (drugim/pierwszym polskim uczestnikiem był Henryk Bronisław Arctowski, jego o rok starszy naukowy „rywal” $)^{40}$.

Po wykładzie wprowadzającym zostało przedstawionych siedmiu uczestników wyprawy. Byli to młodzi mężczyźni (najmłodszy miał 22 lata, najstarszy -42). Wszyscy odbyli zaprawę wysokogórska, a czterech wcześniej specjalizowało się w taternictwie. Za "geograficzne" upamiętnienie możemy uznać nazwanie miejsc na mapie Spitsbergenu ich nazwiskami (sześć lodowców i jeden szczyt górski na cześć kierownika wyprawy), natomiast za ich historyczno-wizualne uwiecznienie - właśnie omawiany film. Zważywszy na fakt odnalezienia filmu po 85 latach od czasu, w którym dzieje się akcja, a więc w momencie, gdy nie mógł już żyć żaden z jej uczestników, możemy wręcz mówić o artystycznym (lub w pewnym sensie naukowym) „ożywieniu” ich sylwetek. Do takiego wniosku skłaniają wrażenia po pierwszych seansach, w których uczestniczyli specjaliści od lat zajmujący się przedwojennymi narracjami polarnymi (Agata Lubowicka) oraz praktycy (Ilona Wiśniewska ${ }^{41}$ ). Czym innym bowiem jest czytać i analizować teksty nieżyjących pionierów danej dziedziny, a czym innym móc zobaczyć, jak wyglą- 
dali w młodym wieku, jeszcze przed zdobyciem sławy (tytułów, dorobku naukowego lub popularyzatorskiego). Wartość źródłową w znaczeniu bezpośrednim podnosi fakt, że w większości przypadków są to jedyne znane portrety filmowe uczestników wyprawy.

Tabela 1. Uczestnicy wyprawy do Ziemi Torella (oprac. własne)

\begin{tabular}{|c|c|}
\hline Komentarz narratora zza kadru & Podstawowe personalia \\
\hline $\begin{array}{l}\text { Kierownik wyprawy inżynier Stefan } \\
\text { Bernadzikiewicz }\end{array}$ & $\begin{array}{l}\text { (1902-1939), inżynier mechanik, asystent } \\
\text { na Politechnice Warszawskiej, } \\
\text { uczestniczył we wszystkich trzech } \\
\text { przedwojennych wyprawach na } \\
\text { Spitsbergen (1934, 1936, } 1938 \text { r.) } \\
\text { i w wyprawie na Grenlandię w } 1937 \text { r. } \\
\text { Za zasługi w badaniach Svalbardu } \\
\text { Norwegia odznaczyła go Krzyżem } \\
\text { Kawalerskim św. Olafa I klasy. W latach } \\
\text { 1937-1938 był prezesem Klubu } \\
\text { Wysokogórskiego przy PTT. Zginął } \\
\text { w Himalajach. Jego nazwiskiem nazwano } \\
\text { szczyt o wysokości } 751 \text { m w Górach } \\
\text { Piłsudskiego na Spitsbergenie } \\
\text { (Bernadzikiewiczfjellet). }\end{array}$ \\
\hline Triangulator major Sylweriusz Zagrajski & $\begin{array}{l}\text { (1892-1940), zawodowy oficer, pracownik } \\
\text { Wojskowego Instytutu Geograficznego. } \\
\text { Jego nazwiskiem nazwano lodowiec } \\
\text { pomiędzy Warszawaryggen a Lysefjellet } \\
\text { (Zagrajskibreen). }\end{array}$ \\
\hline Fotogrametra kapitan Antoni Zawadzki & $\begin{array}{l}\text { (1896-1974), zawodowy oficer, pracownik } \\
\text { Wojskowego Instytutu Geograficznego. } \\
\text { Na Spitsbergen nie wrócił, wziął } \\
\text { natomiast udział w wyprawie na } \\
\text { Grenlandię w } 1937 \text { r. Jego nazwiskiem } \\
\text { nazwano lodowiec na południe od } \\
\text { Penckbreen (Zawadzkibreen). }\end{array}$ \\
\hline Geolog doktor Zbigniew Różycki & $\begin{array}{l}\text { (1906-1988), pracował w Zakładzie } \\
\text { Geologii i Paleontologii Uniwersytetu } \\
\text { Warszawskiego. Wyniki badań z } 1934 \text { r. } \\
\text { opublikował dopiero w } 1959 \text { r. Zbadał } \\
\text { profil geologiczny Ziemi Torella z okresu } \\
\text { jury i kredy. Jego nazwiskiem nazwano } \\
\text { lodowiec schodzący do Zawadzkibreen } \\
\text { (Rozyckibreen). }\end{array}$ \\
\hline $\begin{array}{l}\text { Meteorolog Stanisław Siedlecki. } \\
\text { Jest również w drużynie doświadczony } \\
\text { polarnik, który spędził rok cały na }\end{array}$ & $\begin{array}{l}\text { (1912-2002), jego nazwiskiem nazwano } \\
\text { lodowiec w Górach Piłsudskiego } \\
\text { (Siedleckibreen). Po powrocie z wyprawy }\end{array}$ \\
\hline
\end{tabular}




\begin{tabular}{|c|c|}
\hline $\begin{array}{l}\text { pobliskiej Wyspie Niedźwiedziej. Jego } \\
\text { obecność sprawia, że i my, nowicjusze } \\
\text { wśród lodów podbiegunowych, czujemy } \\
\text { się w obozie jak w domu. }\end{array}$ & $\begin{array}{l}\text { do Ziemi Torella zmienił kierunek } \\
\text { studiów na geologię, w } 1949 \text { r. uzyskał } \\
\text { stopień doktora, pięć lat później-docenta. } \\
\text { W drugiej połowie lat } 50 \text {. zorganizował } \\
\text { wyprawy na Spitsbergen i kierował nimi } \\
\text { (rekonesans w } 1956 \text { r., główna wyprawa } \\
\text { w } 1957 \text { i } 1958 \text { r., trzy wyprawy do stacji } \\
\text { w Hornsundzie: 1959, 1960, } 1962 \text { r.). } \\
\text { W } 1971 \text { r. przyjął obywatelstwo } \\
\text { norweskie, na emeryturę przeszedł } \\
\text { w } 1980 \text { r. W } 2007 \text { r. Polskiej Stacji Polarnej } \\
\text { na Spitsbergenie nadano jego imię. }\end{array}$ \\
\hline $\begin{array}{l}\text { Radiotelegrafista i fotograf Henryk } \\
\text { Mogilnicki }\end{array}$ & $\begin{array}{l}\text { (1906-1999), chemik, uczestnik dwóch } \\
\text { wypraw na Spitsbergen (1934 i } 1959 \text { r.). } \\
\text { Podczas wyprawy do Ziemi Torella } \\
\text { wykonał ponad } 200 \text { fotografii. W czasie } \\
\text { drugiej z wypraw poznał Jana } \\
\text { Szupryczyńskiego (kierownika } \\
\text { największej wyprawy, z } 1978 \text { r.). Został } \\
\text { pochowany na cmentarzu na Powązkach. } \\
\text { Jego nazwiskiem nazwano lodowiec } \\
\text { w Górach Piłsudskiego (Mogilnickibreen). }\end{array}$ \\
\hline $\begin{array}{l}\text { Radiotelegrafista i kinooperator inżynier } \\
\text { Witold Biernawski }\end{array}$ & $\begin{array}{l}\text { (1898-1957), jego nazwiskiem nazwano } \\
\text { lodowiec w północnej partii Gór } \\
\text { Piłsudskiego (Biernawskibreen). }\end{array}$ \\
\hline
\end{tabular}

Spośród trzech scharakteryzowanych wyżej filmów Do Ziemi Torella zawiera najwięcej akcentów polsko-norweskich. Pokazany i wymieniony jest port w Tromsø (nazwanym w filmie „starożytnym miastem”), dwukrotnie wspomniana jest rola norweskich przewoźników, którzy transportują członków polskiej wyprawy na Spitsbergen. Gdy wracają, narrator nazywa ich mitymi łowcami fok $i$ wielorybów, co powoduje skojarzenie z narracją kolonialną. Także z tego punktu widzenia oraz przez pryzmat propagandy II RP można interpretować pokazane w dwóch ujęciach flagi: wyżej, większa, polską i niżej, mniejszą, norweską. Znaczący jest komentarz: I oto po raz pierwszy załopotała na wietrze polarnym Spitsbergenu zdobywcza flaga polska w towarzystwie barw Norwegii, patronujacej ojcowsko naszym pierwszym krokom wśród lodów Pótnocy. Druga część zdania osłabia nieco agresywny, polityczny wydźwięk. Z filologicznego punktu widzenia zabawny jest pleonazm patronować ojcowsko ${ }^{42}$.

\section{Zakończenie}

Powyższy tekst należy traktować jako wstęp. Konieczne są szersze badania obrazu Svalbardu w filmie, zarówno lat 30., jak i późniejszych okresów. Oprócz kinematografii polskiej obszarem tym zajmowały się głównie Norwegia i Związek 
Radziecki, a później Rosja. Na kolejnych etapach badań interesujących wniosków mogą dostarczyć analizy porównawcze tych obrazów. Również niedawno odnaleziony film Do Ziemi Torella, dzięki jego digitalizacji, wykonaniu i dodaniu napisów w języku angielskim oraz dzięki niniejszemu opracowaniu a także zaplanowanym pokazom ${ }^{43}$, z pewnością stanie się jeszcze tematem publikacji ${ }^{44}$, które mogą stanowić przedmiot badań z punktu widzenia recepcji (critical discourse analysis). Sprawozdanie z częstotliwości podejmowania tematyki polarnej, zwłaszcza obrazu Svalbardu, w filmie polskim przedstawia poniższa tabela. Zawarliśmy w niej głównie filmy powstałe "odgórnie”, zrealizowane przez wytwórnie państwowe z jednym wyjątkiem współczesnego reportażu z 2017 r. Dalszych kwerend wymaga ustalenie, czy, kiedy i jak przedstawiano w telewizji polskiej (państwowej, jak i komercyjnej) stację Polskiej Akademii Nauk w Hornsundzie i inne stacje prowadzone na Svalbardzie przez polskie ośrodki naukowe ${ }^{45}$.

Tabela 2. Wykaz wybranych polskich filmów dotyczących Svalbardu. Zastosowane skróty: PKF - Polska Kronika Filmowa, PAT - Polska Agencja Telegraficzna, WFO - Wytwórnia Filmów Oświatowych, TVP - Telewizja Polska. (oprac. własne wg stanu na październik 2020 r.)

\begin{tabular}{|c|c|c|c|c|c|c|c|}
\hline $\mathrm{nr}$ & Tytuł & Reżyser & $\begin{array}{l}\frac{\pi}{0} \\
\frac{1}{J} \\
\frac{0}{0} \\
0 \\
0\end{array}$ & 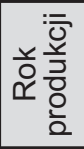 & $\begin{array}{l}\text { : } \\
\text { on } \\
\text { 옴 } \\
\text { 곰 }\end{array}$ & Forma & $\begin{array}{l}\text { Miejsce } \\
\text { przecho- } \\
\text { wywania }\end{array}$ \\
\hline 1. & Do Ziemi Torella & W. Biernawski & Panta-film & 1934 & $9^{\prime} 22^{\prime \prime}$ & Dokument & WFO \\
\hline 2. & $\begin{array}{c}\text { Ku wiecznym } \\
\text { lodom Spitsbergenu }\end{array}$ & W. Biernawski & $?$ & 1934 & $?$ & Dokument & $?$ \\
\hline 3. & $\begin{array}{l}\text { Wśród mórz } \\
\text { Arktyki }\end{array}$ & $\begin{array}{c}\text { C. Centkiewicz } \\
(?)\end{array}$ & PAT & 1937 & $1^{\prime} 11^{\prime \prime}$ & Dokument & \\
\hline 4. & $\begin{array}{l}\text { Wyspa mgiet } \\
\text { i wichrów }\end{array}$ & $\begin{array}{c}\text { C. Centkiewicz } \\
(?)\end{array}$ & PAT & 1937 & $1^{\prime} 11^{\prime \prime}$ & Dokument & \\
\hline 5. & Na Spitzbergen & & PKF & $\begin{array}{c}1957 / \\
28 \mathrm{~A}\end{array}$ & $43^{\prime \prime}$ & Dokument & \\
\hline 6. & Kwitnaca Arktyka & W. Puchalski & WFO & $\begin{array}{l}1958 / \\
1959\end{array}$ & $8^{\prime} 56^{\prime \prime}$ & Dokument & WFO \\
\hline 7. & Śpiewające góry & W. Puchalski & WFO & $\begin{array}{l}1958 / \\
1959\end{array}$ & $9^{\prime} 21^{\prime \prime}$ & Dokument & WFO \\
\hline 8. & $\begin{array}{l}\text { W tundrach } \\
\text { Arktyki }\end{array}$ & W. Puchalski & WFO & $\begin{array}{l}1958 / \\
1959\end{array}$ & $85^{\prime \prime}$ & Dokument & WFO \\
\hline 9. & $\begin{array}{l}\text { Wśród gór i dolin } \\
\text { Arktyki }\end{array}$ & W. Puchalski & WFO & $\begin{array}{l}1958 / \\
1959\end{array}$ & $13^{\prime} 44^{\prime \prime}$ & Dokument & WFO \\
\hline 10. & Wyspa piór i puchu & W. Puchalski & WFO & $\begin{array}{l}1958 / \\
1959\end{array}$ & $10^{\prime} 03^{\prime \prime}$ & Dokument & WFO \\
\hline 11. & $\begin{array}{c}\text { Maty reportaż spod } \\
\text { bieguna }\end{array}$ & J. Brzozowski & WFO & 1959 & 2 akty & Dokument & WFO \\
\hline
\end{tabular}




\begin{tabular}{|c|c|c|c|c|c|c|c|}
\hline 12. & $\begin{array}{c}\text { Notatki z rogatej } \\
\text { ziemi }\end{array}$ & J. Brzozowski & WFO & 1959 & 1 akt & Dokument & WFO \\
\hline 13. & $\begin{array}{l}\text { Pótnocna } \\
\text { Norwegia }\end{array}$ & J. Brzozowski & WFO & 1959 & $18^{\prime}$ & Dokument & WFO \\
\hline 14. & Szpicbergi & J. Brzozowski & WFO & 1959 & $17^{\prime} 49^{\prime \prime}$ & Dokument & WFO \\
\hline 15. & $\begin{array}{c}\text { W Zatoce Biatych } \\
\text { Niedźwiedzi }\end{array}$ & J. Brzozowski & WFO & 1960 & $74^{\prime}$ & $\begin{array}{c}\text { Reportaż } \\
\text { przyrodniczy }\end{array}$ & WFO \\
\hline 16. & $\begin{array}{c}\text { Na dalekiej } \\
\text { pótnocnej wyspie }\end{array}$ & J. Brzozowski & WFO & 1960 & & Dokument & WFO \\
\hline 17. & Na biatym szlaku ${ }^{46}$ & $\begin{array}{c}\text { J. Brzozowski, } \\
\text { A. Wróbel }\end{array}$ & & 1962 & $73^{\prime} 54^{\prime \prime}$ & Fabularny & \\
\hline 18. & $\begin{array}{l}\text { U brzegów } \\
\text { Skandynawii }\end{array}$ & $\begin{array}{c}\text { J. Czecz, } \\
\text { W. Puchalski }\end{array}$ & WFO & 1965 & $9^{\prime} 22^{\prime \prime}$ & Dokument & WFO \\
\hline 19. & \begin{tabular}{c|}
99 dni na \\
Spitsbergenie \\
(Dziewiéćdziesiąt \\
dziewiéć dni na \\
Spitsbergenie)
\end{tabular} & R. Czajkowski & TVP & 1971 & $30^{\prime}$ & Dokument & \\
\hline 20. & $\begin{array}{c}\text { Lato na } \\
\text { Spitsbergenie }\end{array}$ & W. Zadrowski & $\begin{array}{l}\text { Interpress- } \\
\text {-Film }\end{array}$ & 1975 & & Dokument & \\
\hline 21. & $\begin{array}{l}\text { Pocztówka ze } \\
\text { Spitsbergenu }{ }^{47}\end{array}$ & J. Gruza & & 1975 & $56^{\prime} 14^{\prime \prime}$ & $\begin{array}{l}\text { 10. odc. serialu } \\
\text { Czterdziestolatek }\end{array}$ & \\
\hline 22. & Spitsbergen & ? & TVP? & 1978 & $19^{\prime} 47^{\prime \prime}$ & Dokument & $?$ \\
\hline 23. & Jak tam jest & A. Bednarek & WFO & 1980 & $10^{\prime} 02^{\prime \prime}$ & Dokument & WFO \\
\hline 24. & $\begin{array}{l}\text { Alina i Czesław } \\
\text { Centkiewiczowie }\end{array}$ & J. Zajiček & WFD & 1980 & & Dokument & WFO \\
\hline 25. & Zimny lad & K. Błahij & $\begin{array}{l}\text { Interpress- } \\
\text {-Film }\end{array}$ & 1984 & $27^{\prime} 55^{\prime \prime}$ & Dokument & \\
\hline 26. & $\begin{array}{l}\text { Za Kołem } \\
\text { Polarnym }\end{array}$ & $\begin{array}{c}\text { R. Biczyńska } \\
\text { (red.) }\end{array}$ & PKF & $\begin{array}{c}1986 / \\
51\end{array}$ & 2'17" & Dokument & \\
\hline 27. & \begin{tabular}{|c|} 
Polarne wyprawy \\
Włodzimierza \\
Puchalskiego
\end{tabular} & $\begin{array}{c}\mathrm{R} . \\
\text { Wyrzykowski }\end{array}$ & WFO & 1986 & $28^{\prime} 01^{\prime \prime}$ & Dokument & WFO \\
\hline 28. & $\begin{array}{c}\text { Polarna Stacja } \\
\text { Hornsund }\end{array}$ & B. Kapuściński & $\begin{array}{l}\text { Interpress- } \\
\text {-Film }\end{array}$ & 1988 & $27^{\prime} 53^{\prime \prime}$ & Dokument & \\
\hline 29. & Stanistaw Siedlecki & W. Rollny & WFO & 1988 & $21^{\prime} 36^{\prime \prime}$ & Dokument & WFO \\
\hline
\end{tabular}




\begin{tabular}{|c|c|c|c|c|c|c|c|}
\hline 30 & Spitsbergen & R. Czajkowski & TVP & 1991 & $30^{\prime}$ & Dokument & $\begin{array}{l}\text { Archiwum } \\
\text { TVP }\end{array}$ \\
\hline 31 & Ekologia arktyczna & I. Bartólewska & TVP & 1992 & & Dokument & \\
\hline 32 & Polonica arktyczne & I. Bartólewska & TVP & 1992 & $27^{\prime} 52^{\prime \prime}$ & Dokument & $\begin{array}{l}\text { Archiwum } \\
\text { TVP }\end{array}$ \\
\hline 33 & Ślad na lodzie & I. Bartólewska & TVP & 1993 & $27^{\prime} 03^{\prime \prime}$ & Dokument & \\
\hline 34 & $\begin{array}{l}\text { Polska polarna } \\
\text { stacja w } \\
\text { Hornsundzie }\end{array}$ & $\begin{array}{c}\text { R. } \\
\text { Wyrzykowski }\end{array}$ & $\begin{array}{l}\text { WFO dla } \\
\text { TVP }\end{array}$ & 1993 & $27^{\prime} 15^{\prime \prime}$ & Dokument & \\
\hline 35 & $\begin{array}{c}\text { Jak tam jest - rok } \\
\text { w Hornsundzie }\end{array}$ & $\begin{array}{c}\text { R. } \\
\text { Wyrzykowski }\end{array}$ & WFO & 1994 & $26^{\prime} 27^{\prime \prime}$ & Dokument & WFO \\
\hline 36 & $\begin{array}{l}\text { Wyprawy z } \\
\text { Hornsundu }\end{array}$ & $\begin{array}{c}\text { R. } \\
\text { Wyrzykowski }\end{array}$ & WFO & 1994 & $24^{\prime} 11^{\prime \prime}$ & Dokument & \\
\hline 37 & $\begin{array}{c}\text { Alfred Jahn (film } \\
\text { cyklu Profesor } \\
\text { Wroctaw) }\end{array}$ & L. Kaletowa & & 2013 & & Dokument & \\
\hline 38 & Świat się kręci & & TVP & 2016 & $\begin{array}{c}25^{\prime} 20^{\prime \prime} \\
- \\
37^{\prime} 39^{\prime \prime}\end{array}$ & $\begin{array}{c}\text { Program } \\
\text { telewizyjny }\end{array}$ & \\
\hline 39 & $\begin{array}{l}\text { Spitsbergen } \\
\text { (cz. } 1 \text { i } 2)\end{array}$ & M. Mosak & & 2017 & $\begin{array}{c}12^{\prime} 35^{\prime \prime} \\
+ \\
12^{\prime} 23^{\prime \prime}\end{array}$ & & online \\
\hline 40 & Ice motion & K. Witek & PAN & 2019 & $21^{\prime} 45^{\prime \prime}$ & Dokument & \\
\hline
\end{tabular}

${ }^{1}$ D. Rozmus, Traktat swalbardzki - wykorzystane szanse?, „Roczniki Administracji i Prawa” 2017, nr XVII (zeszyt specjalny), s. 270.

${ }^{2}$ Traktat svalbardzki ma dość obszerną i różnorodną literaturę. Zob. m.in. L. Morkunas, Kissing Cousins: https://www.academia.edu/30938297/Kissing_Cousins_The_Svalbard_Treaty_and_Asian-Pacific_States (dostęp: 1.01.2020).; L. Campopiano, Non-State Actors in the Arctic: Lessons from the 1920 Svalbard Treaty Negotiations, "St Andrews Historical Journal" 2019, t. 8, nr 1, https://www.academia.edu/39940278/Non-state_actors_in_the_Arctic_Lessons_from_the_1920_Svalbard_Treaty_negotiations (dostęp: 1.01.2020).
${ }^{3}$ J. Szupryczyński, Pierwsza polska wyprawa polarna na Spitsbergen, „Przegląd Geograficzny" 2015, t. 87, nr 1, s. 168.

${ }^{4}$ Tenże, dz. cyt. Por. P. Köhler, Z Legionowa na Wyspe Niedźwiedzia. I polska wyprawa polarna 1932-1933, "Rocznik Legionowski” 2014, t. 7, s. 31.

${ }^{5}$ Zob. A. Lubowicka, Jak dołaczyć do grona "państw kulturalnych". Historia wizualna pierwszej polskiej ekspedycji arktycznej w dwudziestoleciu międzywojennym, w: Okno na przeszłość. Szkice z historii wizualnej, t. 2, red. D. Skotarczak, J. Szymala, Księgarnia Akademicka, Kraków 2020, s. 35-68.

${ }^{6}$ Por. tytuły publikacji Piotra Köhlera podane w bibliografii końcowej. 
${ }^{7}$ Zob. b. a., „Biuletyn Informacyjny Wydziału Nauk Historycznych i Pedagogicznych Uniwersytetu Wrocławskiego" 2019, nr 28 (XI), s. 11; por. A. Lubowicka, dz. cyt., s. 68.

${ }^{8}$ Por. J. Szymala, Włodzimierz Puchalski (1909-1979) - przyrodnik i artysta między Dolnym Ślaskiem a Svalbardem, "Zeszyty Artystyczne” 2020, nr 37.

${ }^{9}$ Akapit na podstawie P. Köhler, Z Legionowa na Wyspę Niedźwiedzia... dz. cyt. oraz J. Szupryczyński, Pierwsza polska wyprawa polarna, "Przegląd Geograficzny” 2013, t. 85, nr 1, s. 123-160.

${ }^{10}$ Zob. J. Lugeon, Rok Polarny 1932-1933 i wspótpraca Polski, "Przegląd Geograficzny” 1930, t. 10, nr 3-4, s. 193-206; tenże, Polska Wyprawa Polarna na Wyspę Niedźwiedzią w Roku Polarnym 1932-1933 - Uwagi wstępne, „Biuletyn Towarzystwa Geofizycznego" 1933, nr 7-8, s. 3-5; tenże, Polski Rok Polarny na Wyspie Niedźwiedziej, „Przegląd Geograficzny” 1933, t. 13, nr 1, s. 1-47.

${ }^{11} \mathrm{http}: / /$ www.sejm.gov.pl/sejm7.nsf/wypowiedz.xsp?posiedzenie $=21 \& d z i e n=1 \& w y p=149$ (dostęp: 1.01.2020).

${ }^{12}$ Biografia i dorobek Stanisława Siedleckiego są solidnie opracowane w literaturze fachowej, Siedlecki był także rekordzistą w liczbie odbytych wypraw polarnych, najczęściej również pojawiał się $\mathrm{w}$ filmach jako bohater (jak w Do Ziemi Torella) lub konsultant (w filmach późniejszych, w tym osobnej monografii filmowej Wandy Rollnej jemu poświęconej).

${ }^{13} \mathrm{http}$ ://www.repozytorium.fn.org.pl/?q=pl/node/9897 (dostęp: 1.01.2020).

14 Za konsultację dziękujemy dr Agacie Lubowickiej z Uniwersytetu Gdańskiego.

${ }^{15}$ Wyspa mgieł $i$ wichrów, http://www.repozytorium.fn.org.pl/?q=pl/node/9897 (dostęp: 1.01.2020).

16 P. Köhler, Z Legionowa na Wyspę Niedźwiedzią... dz. cyt., s. 35.

17 A. Krawczyk, Polskie ślady na Wyspie Niedźwiedziej (1932-1933), "Biuletyn Polarny” 2014, nr 17-18, s. 74.

18 Tamże.

${ }^{19}$ http://www.repozytorium.fn.org.pl/?q=pl/node/8333 (dostęp: 1.01.2020).

${ }^{20} \mathrm{Na}$ temat Polskiej Agencji Telegraficznej zob. wykład Małgorzaty Hendrykowskiej, autorki monografii polskiego przedwojennego filmu dokumentalnego, https://www.youtube.com/watch?v=F9U5UGAU8gk (dostęp: 2.01.2020). PAT zrealizowała także autotematyczny film Wieść, depesza, informacja, który można potraktować jako źródło o cha- rakterze bezpośrednim. Film jest dostępny online, http://www.repozytorium.fn.org.pl/?q=pl/node/10129 (dostęp: 2.01.2020).

${ }^{21}$ A. Krawczyk, dz. cyt. Materiał pochodzi więc najpewniej z początku 1937 r., kiedy Centkiewicz podróżował na pokładzie norweskiego statku myśliwskiego Isfjell przez Morze Białe i Morze Barentsa. Nie mamy pewności, czy wzmiankowaną sekwencję sfilmowano w okolicy Svalbardu. Więcej na temat marszruty Centkiewicza z zimy-wiosny 1937 r. zob. Wyprawa polskiego uczonego na ocean Lodowaty, „,Wiarus” 1937, nr 24, s. 584. Jeszcze więcej informacji na temat tej podróży można znaleźć w dokumentach w Statsarkivet w Tromsø pod odnośnikiem „Norsk Polarinstitutt (med forløpere), 130, mappe: Utenlandske ekspedisjoner Svalbard 1932-1933)". Za udostępnienie tego materiału dziękujemy dr Agacie Lubowickiej.

${ }^{22}$ Wśród mórz Arktyki, dz. cyt.

${ }^{23}$ Zob. J. Szupryczyński, Pierwsza polska wyprawa...dz. cyt., s. 167-178; P. Köhler, Polska wyprawa na Spitsbergen w 1934 roku, ,Kwartalnik Historii Nauki i Techniki" 2015, r. 60, nr 2, s. 117-140.

${ }^{24}$ Por. Polska wyprawa polarna na Spitsberg sfilmowana, „Wiadomości Filmowe” 1935, r. 3, nr 24 (15 grudnia), tekst dostępny online, https://polona.pl/item/wiadomosci-filmoweczasopismo-ilustrowane-r-3-nr-24-15-grudnia-1935,NTgwNDE1NjQ/16/\#info:metadata (dostęp: 7.9.2020). Zob. także I. Nowak-Zaorska, Polski film oświatowy w okresie międzywojennym, Kraków 1969, s. 148, 150, 157 -159. Za konsultację, w tym wskazanie tych dwóch opracowań, serdecznie dziękujemy Pani prof. Małgorzacie Hendrykowskiej.

${ }^{25}$ Kwerendę przeprowadziła dr Agata Lubowicka z Uniwersytetu Gdańskiego. Informację przekazał Øivind Hanche, bibliotekarz naukowy z Filmdokumentasjon Film og kringkasting (norweska Biblioteka Narodowa).

${ }^{26}$ A. Kępiński, H. Sandøy, Polsko-norweska historia filmowa, w: Kino Norwegii, red. J. E. Holst, P. Urbanik, tłum. P. Urbanik, M. Kłos, MFF Nowe Horyzonty, Warszawa - Kraków 2011, s. 329. Por. M. Sokół-Rudowska, Ludwik Szaciński-powstaniec i fotograf, w: Polacy w Norwegii (XIX-XXI w.). Wybór materiałów źródłowych, Archiwum Państwowe w Krakowie, Kraków 2010.

${ }^{27}$ En vidunderlig film fra Svalbard, "Nationen" (Oslo), 18 września 1936 r. Tekst odnaleziony i przetłumaczony przez dr Agatę Lubowicką. Ivar Stokkeland z Norwegian Polar 
Institute ustalił, że materiał również opublikowano 22 września 1936 r. w „Lofotposten" (Svolvær; ten sam tekst mógł się pojawić w kilku norweskich czasopismach jako informacja prasowa). Oboje badacze zechcą przyjąć podziękowania za przeprowadzenie kwerendy.

28 Świadczy o tym fakt, że w "Aftenposten" (Oslo) z dnia projekcji filmu nie ma wzmianki na jego temat. Informację sprawdziła prof. Roswitha Skare na prośbę dr Agaty Lubowickiej. Więcej informacji na temat przygotowania tego pokazu filmowego można znaleźć w dokumentach w Statsarkivet w Tromsø pod odnośnikiem „Norsk Polarinstitutt (med forløpere), 130. Za udostępnienie tego materiału dziękujemy dr Agacie Lubowickiej.

${ }^{29}$ Jednakże, na podstawie wzmianki odnalezionej i udostępnionej nam przez dr Agatę Lubowicką oraz zweryfikowanej przez Ivara Stokkelanda, film był postrzegany jako fotograficzne arcydzieło, w którym każdy kadr przechowuje piękno, co daje nam, jak nigdy dotąd, wrażenie nieskończenie wspaniatej, ale i przerażająco dzikiej surowej pótnocnej wyspy (En vidunderlig film fra Svalbard), „Nationen” (Oslo), 18 września 1936 r.

${ }^{30} \mathrm{http}: / / w w w \cdot r a d i o k r a k o w \cdot p l / a u d y c j e / w-k r e-$ gu-nauki/audycja-z-dn16092018-r/ (audycja z 16.09.2018 r., dostęp: 1.02.2020).

${ }^{31}$ Do Ziemi Torella gatunkowo można także zaklasyfikować do filmu ekspedycyjnego. Z tamtego okresu możemy wymienić przynajmniej dwa filmy norweskie dotyczące Svalbardu: Vårtokt til Bjørnøya (Wiosenna podróż na Wyspę Niedźwidzia) oraz Svalbardtokt (Wyprawa na Svlbard), wyreżyserowany przez amatora Thora Iversena (1873-1953), oba z 1930 r., tj. przed realizacją polskiego filmu. Dwa norweskie filmy, z których każdy trwa około dziesięciu minut, są nieme i nie są tak wyrafinowane jak Do Ziemi Torella. Mniej koncentrują się na indywidualności człowieka i celach badawczych, a bardziej na wydobyciu węgla, łowiectwie i rybołówstwie jako pracy zespołowej. Jednak ewidentny podziw Iversena dla oszałamiającej przyrody Svalbardu jest dość podobny do podziwu Biernawskiego. Więcej na temat Iversena i gatunku norweskiego filmu ekspedycyjnego zob. w artykule Bjørna Sørenssen'a, w bibliografii.

${ }^{32}$ Miał na myśli pełnometrażowy dokument amerykański With Byrd at the South Pole z 1930 r. Lotnik Richard Byrd (1888-1957) w 1926 r. dokonał przelotu nad Spitsberge- nem, w 1928 r. rozpoczął wyprawę na Antarktydę, rok później dokonał przelotu nad Biegunem Południowym, zmarł w tym samym roku, co reżyser Do Ziemi Torella, Witold Biernawski. Film With Byrd at the South Pole, nakręcony przez dwóch profesjonalnych operatorów i wydany przez Paramount, jest o wiele wspanialszy niż Do Ziemi Torella. Został nagrodzony Oscarem za najlepsze zdjęcia (jako jedyny dokument, który kiedykolwiek uzyskał takie wyróżnienie). Podobnie jak Do Ziemi Torella, With Byrd at the South Pole zawiera również słowo wstępne (autorstwa samego Byrda), „wprowadzające" portrety głównych członków ekipy i dramatyczną muzykę orkiestrową. Istnieje duże prawdopodobieństwo, że Do Ziemi Torella celowo wzorowano na With Byrd at the South Pole.

${ }^{33}$ Polska wyprawa polarna na Spitzberg, "Kurjer Warszawski" 1935, r. 115, nr 352, s. 14.

${ }^{34}$ Tamże.

${ }^{35}$ Film Puchalskiego był zdigitalizowany wcześniej i włączony $w$ pakiet wspomnianych pięciu filmów arktycznych z lat 1957-1958 .

${ }^{36}$ Zob. J. Szymala, Na Zachodzie bez zmian. Historia, powieść, film, w: tegoż, Film - Historia - Turystyka, Księgarnia Akademicka, Kraków 2016, s. 101-128. Zaprezentowanie (wymienienie i pokazanie jeden po drugim) członków wyprawy przypomina także ilustrowane wyliczanie aktorów we wczesnych filmach niemych, jak w filmie Władysława Starewicza Christmas Eve / Wigilia (1913).

${ }^{37} \mathrm{P}$. Witek, Historyczny film dokumentalny jako dyskurs metaforyczny, w: Media audiowizualne w warsztacie historyka, red. D. Skotarczak, Instytut Historii Uniwersytetu im. Adama Mickiewicza, Poznań 2008, s. 148.

${ }^{38}$ Bracia Goetel pochodzili z Suchej Beskidzkiej; podobnie jak Billy Wilder (1906-2002). Można więc mówić o symbolicznym znaczeniu miasta na mapie miejsc istotnych dla historii wizualnej (wg definicji, w której za część historii wizualnej uznamy nie tylko ilustracje książek, ale i samą literaturę). Zob. Billy Wilder: mistrz kina z Suchej Beskidzkiej, red. K. Żyto, M. Pieńkowski, Warszawa 2011.

39 A. B. Dobrowolski, Historja naturalna lodu, Kasa im. Malinowskiego, Warszawa 1923.

${ }^{40}$ S. Maj, Profesor Antoni Bolesław Dobrowolski (1872-1954) jako geofizyk (życie i działalność), „Przegląd Geograficzny” 2011, z. 3-4, s. 279-290, abstrakt artykułu dostępny online, http://yadda.icm.edu.pl/baztech/element/bw 
meta1.element.baztech-article-BUS8-00160025 (dostęp: 2.01.2020).

${ }^{41}$ Zob. I. Wiśniewska, Białe: zimna wyspa Spitsbergen, Wołowiec 2014; taż, Hen: na północy Norwegii, Wydawnictwo Czarne, Wołowiec 2016. Autorka pracuje nad książkową monografią Polskiej Stacji Polarnej w Hornsundzie im. S. Siedleckiego. Ilonę Wiśniewską można zobaczyć w pierwszej części filmu Spitsbergen (reż. M. Mosak, 2017).

${ }^{42}$ Kwestia przynależności państwowej Svalbardu jest powracającym motywem wizualnym i werbalnym $w$ filmach o Svalbardzie zrealizowanych gdzie indziej, np. w Rosji i Norwegii. Zob. np. przypisy nr 7 i 35 w: A. Rogatchevski, Svalbard on the (Post-)Soviet Screen, „Nordlit” 2020, nr 45, s. 150-174.

${ }^{43}$ Po odnalezieniu filmu pokazy odbyły się za kręgiem polarnym, pokaz w Polsce jest planowany podczas Sympozjum Polarnego w Toruniu (konferencja przeniesiona z 2020 na 2021 r.). Zob. J. Szymala, 100-lecie zawarcia traktatu svalbardzkiego (spitsbergeńskiego). Sprawozdanie z obchodów w Arktyce (luty 2020 r.), sprawozdanie przesłane do publikacji w „Biuletynie Polarnym”.
${ }^{44}$ Mamy nadzieję na odnalezienie i opracowanie drugiego filmu Witolda Biernawskiego, Ku wiecznym lodom Spitsbergenu.

45 Przykładowo materiał taki wyemitowano 24 grudnia 2019 r. w programie „Wydarzenia" na stacji Polsat. Pokazano członków 42. Wyprawy Polarnej Polskiej Akademii Nauk, w tym kierownika, Joannę Perchalut-Mandat, która powiedziała: Nie musimy czekać na "pierwsza gwiazdkę", żeby zasiaść do wieczerzy, ponieważ u nas trwa noc polarna, tak że możemy wybrać dowolna "gwiazdkę" $z a$ oknem", https://www.polsatnews.pl/wideoprogram/2 0191224 - w y d a r zenia1850_6762332/ (dostęp: 4.01.2020).

${ }^{46} \mathrm{~W}$ filmie wykorzystano fragmenty zrealizowanych na Spitsbergenie dokumentów Jarosława Brzozowskiego, natomiast akcja filmu rozgrywa się na Grenlandii (filmowanej także w Tatrach).

${ }^{47}$ Spitsbergen jest w filmie jedynie wzmiankowany, ale nie pokazany, nawet na tytułowej pocztówce.
Jacek Szymala

Andrei Rogatchevski
Doktor nauk humanistycznych, badacz historii wizualnej, kulturoznawca. Opublikował dwa tomy autorskie: Film Historia - Turystyka (2016) oraz Poøstanie kozackie 1648-1658. Studium z historii wizualnej (2019). Redaktor prowadzacy serii wydawniczej „Historia w Mediach” (wydawnictwo Ksiegarnia Akademicka, Kraków). Aktualne zainteresowania naukowe: historia wizualna, Svalbard, film czarnogórski. Członek Polskiego Towarzystwa Badań nad Filmem i Mediami oraz Polskiego Towarzystwa Badania Gier; wykładowca Akademii Polskiego Filmu. Odnalazł przedwojenny filmowy reportaż z polskiej wyprawy na Spitsbergen (Do Ziemi Torella, reż. Witold Biernawski).

Profesor, absolwent Moskiewskiego Uniwersytetu Państwowego im. M. W. Łomonosowa i Uniwersytetu w Glasgow. Wykładał m.in. na Uniwersytecie w Glasgow, Uniwersytecie w Helsinkach, Uniwersytecie Masaryka w Brnie, Uniwersytecie w Ostravie, University of Mainz/Germersheim, Hebrew University of Jerusalem. Obecnie pracuje na stanowisku Profesora Literatury i Kultury Rosyjskiej w UiT The Arctic University of Norway. Wśród jego monografii autorskich 
i tomów redagowanych są: Bribery and Blat in Russia: Negotiating Reciprocity from the Middle Ages to the 1990 (2000), A Biographical and Critical Study of the Russian Writer Eduard Limonov (2003), Filming the Unfilmable: Casper Wrede's "One Day in the Life of Ivan Denisovich" (2010), Punishment as a Crime? Perspectives on Prison Experience in Russian Culture (2014). Ostatnie publikacje książkowe to: Russophone Periodicals in Israel (2016) i A War of Songs: Popular Music and Recent Russia-Ukraine Relations (2019).

\section{Bibliografia}

[b. a.] (2019). Biuletyn Informacyjny Wydziału Nauk Historycznych i Pedagogicznych Uniwersytetu Wrocławskiego, 28 (11), s. 11.

Bernadzikiewicz, S. (1936). Polska wyprawa polarna na Spitsbergen 1934. Cel i organizacja, prace i wyniki. Taternik, 20 (5), ss. 159-173.

Campopiano, L. (2019). Non-State Actors in the Arctic: Lessons from the 1920 Svalbard Treaty Negotiations. St Andrews Historical fournal, 8 (1), ss. 41-50.

Centkiewicz, C. (1934). Wyspa mgieł i wichrów. Warszawa: Towarzystwo Wydawnicze „Rój”.

Chwaściński, B. (1980). Stefan Bernadzikiewicz. W 40-lecie śmierci. Taternik, 56 (2), Ss. 67-68.

Górski, M. (2015). Zimowanie 1932/1933 na Wyspie Niedźwiedziej - eksplozja polskich badań polarnych. Przeglad Geofizyczny, (1-2), ss. 59-76.

Gurgul, H., Krzeptowski, M. (2000). Henryk Mogilnicki (1906-1999) w 65-lecie Polskiej Wyprawy na Spitsbergen. Biuletyn Polarny, (8), ss. 48-49.

Halicki, B. (1938). Trzecia polska wyprawa na Spitsbergen. Wiadomości Muzeum Ziemi, 1 (4), ss. 119-122.

Hendrykowska, M. (2015). Historia polskiego filmu dokumentalnego (1896-1944). Poznań: Wydawnictwo Naukowe Uniwersytetu im. Adama Mickiewicza.

Kępiński, A., Sandøy, H. (2011). Polsko-norweska historia filmowa (tłum. P. Urbanik, M. Kłos). W: J. E. Holst, P. Urbanik (red.), Kino Norwegii (s. 329). Warszawa - Kraków: MFF Nowe Horyzonty.

Köhler, P. (2013). Stanisław Siedlecki (1912-2002) - polarnik, taternik, geolog. Stulecie urodzin. Kwartalnik Historii Nauki $i$ Techniki, 58 (3), ss. 61-80.

Köhler, P. (2014). Osiemdziesięciolecie polskiej wyprawy na Wyspę Niedźwiedzią. Biuletyn Polarny, (17-18), ss. 62-66.

Köhler, P. (2014). Z Legionowa na Wyspę Niedźwiedzią. I polska wyprawa polarna 1932-1933. Rocznik Legiono\%ski, 7, ss. 30-38.

Köhler, P. (2015). Polska wyprawa na Spitsbergen w 1934 roku. Kwartalnik Historii Nauki i Techniki, 60 (2), ss. 117-140.

Köhler, P. (2016). Druga polska wyprawa na Spitsbergen w 1936 roku. Kïartalnik Historii Nauki $i$ Techniki, 61 (4), ss. 135-143.

Köhler, P. (2018). Polska wyprawa na Spitsbergen w 1938 roku. Kæ̈artalnik Historii Nauki i Techniki, 63 (2), ss. 7-27. 
Krawczyk, A. (2014). Polskie ślady na Wyspie Niedźwiedziej (1932-1933). Biuletyn Polarny, (17-18), ss. 73-75.

Lubowicka, A. (2020). Jak dołączyć do grona „państw kulturalnych”. Historia wizualna pierwszej polskiej ekspedycji arktycznej w dwudziestoleciu międzywojennym. W: D. Skotarczak, J. Szymala (red.), Okno na przeszłość. Szkice z historii wizualnej (t. 2, ss. 35-70). Kraków: Księgarnia Akademicka.

Laszkiewicz, S. (1945). Szum młodości. Edinburgh: Składnica Księgarska.

Maj, S. (2011). Profesor Antoni Bolesław Dobrowolski (1872-1954) jako geofizyk (życie i działalność). Przeglad Geograficzny, (3-4), ss. 279-290.

Maj, S. (2014). Pierwsza polska wyprawa polarna na Wyspę Niedźwiedzią (1932-1933). Przeglad Geofizyczny, (3-4), ss. 175-186.

Niekrasz, L. (1978). Gdzie Polska, gdzie Svalbard. Warszawa: Młodzieżowa Agencja Wydawnicza.

Nowak-Zaorska, I. (1969). Polski film ośziatowy w okresie międzywojennym. Kraków: Zakład Narodowy im. Ossolińskich.

Rogatchevski, A. (2020). Svalbard on the (Post-)Soviet Screen. Nordlit, (45), ss. 150-174 .

Rozmus, D. (2017). Traktat Svalbardzki - wykorzystane szanse?. Roczniki Administracji i Praza, 17 (zeszyt specjalny), ss. 269-287.

Różycki, S. Z. (1936). Wyprawa na Spitsbergen w 1934 roku. Przeglad Geograficzny, 15, SS. 119-137.

Różycki, S. Z. (1936). Ziemia Torella - teren działania polskiej wyprawy polarnej 1934. Taternik, 20 (5), ss. 173-181.

Różycki, S. Z. (1973). Z historii polskich wypraw na Spitsbergen. Czasopismo Geograficzne, 44, ss. 139-145.

Siedlecki, S. (1935). Polska Wyprawa Polarna na Spitsbergen. Wierchy, 13, ss. 34-45.

Siedlecki, S. (1938). Crossing West Spitsbergen from South to North. Sæertrykk av Norsk Geografisk Tidsskrift, 7 (2), ss. 79-91.

Siedlecki, S. (1938). Przejście z południa na północ przez Zachodni Spitsbergen. Wierchy, 16, ss. 118-135.

Sørenssen, B. (2017). Thor Iversen and Arctic Expedition Film on the Geographical and Documentary Fringe in the 1930s. W: E. Frisvold Hanssen, M. Fosheim Lund (red.), Small Country, Long Fourneys: Norwegian Expedition Films (ss. 116-135). Oslo: Nasjonalbiblioteket.

Szupryczyński, J. (1975). Eksploracje naukowe Spitsbergenu. Warszawa: Państwowe Wydawnictwo Naukowe.

Szupryczyński, J. (2007). Eksploracje Spitsbergenu. Przeglad Geograficzny, 71 (3-4), SS. 567-592.

Szupryczyński, J. (2013). Pierwsza polska wyprawa polarna. Przeglad Geograficzny, 85 (1), ss. 123-160.

Szupryczyński, J. (2015). Pierwsza polska wyprawa polarna na Spitsbergen. Przeglad Geograficzny, 87 (1), ss. 167-178.

Szymala, J. (2016). Film - Historia - Turystyka. Kraków: Księgarnia Akademicka.

Szymala, J. (2020). Włodzimierz Puchalski (1909-1979) - przyrodnik i artysta między Dolnym Śląskiem a Svalbardem. Zeszyty Artystyczne, 37, ss. 111-119.

Wiśniewska, I. (2014). Białe: zimna zyspa Spitsbergen. Wołowiec: Wydawnictwo Czarne. 
Wiśniewska, I. (2016). Hen: na północy Norwegii. Wołowiec: Wydawnictwo Czarne.

Zagrajski, S. (1935). Prace geodezyjne Polskiej Wyprawy na Spitsbergen w 1934 roku. Wiadomości Stużby Geograficznej, 9 (1-2), ss. 49-122.

\author{
Keywords: \\ Svalbard; \\ Arctic; \\ visual history
}

\begin{abstract}
Jacek Szymala, Andrei Rogatchevski

Svalbard in Polish Films from 1930 s

Polish documentary films about Svalbard have been associated with polar research, conducted by Poles on a regular basis since the 1930s. Since then, over 30 films have been made. In their paper, the authors focus on the film reportage of the first Polish expedition to the island of Spitsbergen from 1934: Do Ziemi Torella (To Torell Land), which was found in 2019, digitized, translated into English and subtitled. They also discuss Polish experiences on the Bear Island and in Northern waters, briefly shown in Wyspa mgiet $i$ zo $i-$ chrów (The Isle of Fogs and Winds) and W'́ród mórz Arktyki (In Arctic Seas), both from 1937. Earlier, Polish Spitsbergen research was limited to natural sciences. They propose to approach it from the perspective of visual history side; then, the analysed films become historical sources - both in the direct and indirect sense (primary and secondary sources). Polish films about Spitsbergen can function as sources for the history of science, for landscape changes, for the history of civilization, polar research, etc. Of course, they also say a great deal about the propaganda and the image of the Arctic in Polish historiography of a given period. The article is a kind of provisional report on a broader project of (re-)discovering and sharing these films.
\end{abstract}

